\title{
Social Satire in Saudi Press: A Study of Khalaf Alharbi's Articles
}

\author{
Hafsah Albarrak
}

Dammam University, Saudi Arabia

\begin{abstract}
The purpose of this paper is to investigate the emergence of satire in Saudi press, focusing on articles by satirist Khalaf Alharbi. Following a review of satire as a literary genre (historically and descriptively) and the social role it has had, particularly through the press, the study analyzes a collection of articles by Alharbi in an attempt to identify the distinctive features of his style. It was found, for example, that he uses a wide variety of rhetorical devices as well as short words, sentences and paragraphs.
\end{abstract}

\section{INTRODUCTION}

\subsection{Purpose of Study (Research Problem)}

This research investigates the emergence of satire in the Saudi press, highlighting its characteristic features with special reference to articles by satirist Khalaf Alharbi intended to bring about social change.

\subsection{Rationale for Study}

It could be argued that no other study has dealt with satirical articles in Saudi press, especially those of Alharbi. The present undertaking distinguishes itself by shedding light on the stylistic features of this Saudi satirist and how he enlists the power of satire as he tries to be an agent of social change.

\subsection{Research Questions}

The research tries to answer the following questions:

1. Are Alharbi's articles truly satirical?

2. Does Alharbi have distinctive satirical style?

3. Does he represent the public rejection of individual and institutional social defects and shortcomings?

\subsection{Definition of Terms}

Caricature: a funny and deformation of a certain feature or idea. The word is derived from an Italian word meaning 'load lifting' and is more connected to painting. Thus, both painting and literature are used to make a comic and sometimes humiliating effect.

Essay: a small piece of writing in prose about a specific topic which may be descriptive or narrative, etc.

Humor: the identification of strange, unfamiliar situations, actions, and expressions to provoke laughter and provide amusement.

Irony: a figure of speech in which words are used in such a way that their intended meaning is different from their usual dictionary meaning.

Juvenalian Satire: an allusion to the Roman satirist Juvenal, known for his satirical writings. Jonathan Swift is the master of Juvenalian Satire

Lampoon: a piece of narrative written to mock the aims or actions of an individual or institution.

Metaphor: a figure of speech which makes an implicit comparison between two things that are unrelated but share some common characteristics. 
Pun: a play on words in which a humorous effect is produced by using a word that suggests two or more meanings.

Trope: a metaphorical use of words in which writers shift from the literal meanings of words to their non-literal meanings. The trope could be a phrase, a word or an image used to create artistic effects.

Wit: a word derived from the old English form witan, meaning 'to know'. It denotes intellectual originality and mental acuity.

\subsection{Methodology}

The inductive analytical method is used in the present study as it appropriate for the purposes it has set for itself. This way, Alharbi's satirical articles can be examined and analyzed to identify the stylistic features that make them distinct and effective.

\subsection{Structure of Study}

Following these introductory sections, the study will make a literature review in section 2 , to be divided into subsections with the headings' Elements of satire' (2.1), 'Historical roots of satire' (2.2), 'Types of satire' (2.3), 'The role of satirical writing' (2.4), 'The emergence of satire in world press' (2.5), and 'Satire in Saudi press' (2.6). Section 3, on the other hand, is about' Khalaf Alharbi as a Saudi satirist' and is divided into two subsections -'Examples of Khalaf Alharbi's satirical articles' (3.1) and 'Khalaf Alharbi's satirical style' (3.2). There is also a conclusion that presents the main findings of the investigation.

\section{LITERATURE REVIEW}

The Arabic word for 'satire', according to Ibnmanzoor (1990), is synonymous with 'underrating' and 'mocking'; a satirical person shows the defects of another person and criticizes their behavior.

\subsection{Elements of Satire}

Satire is a literary genre that tends to present ideas in a thought-provoking way, resulting in astonishment and laughter. It can be considered a rebellion against reality and an intellectual revolution against traditional axioms. It is known as black comedy; it simply tries to laugh at sorrows. Satirical literature is a type of social criticism that derives its material from community sorrows (Akkari, 1991). The major aim of that genre is to touch the wounds of the society in an indirect manner that provokes thinking. Thus, satire describes, analyzes and criticizes the social phenomena in a funny light way (Abukhalil, 2006).

Satire is a type of humor. It aims at attacking the current state of morality, policy, behavior and thinking, which are a result of previous practices. All these foreshadow dangers which need warnings. The satirical art is one type of these warnings. It can also be considered a type of resistance (Omari, 2005) involving a general style of humor which employs a simple, easy language that may be a standard or a vernacular variety. To capture and highlight social defects, satirical writers use many important devices. Ironic titles and cognomen, for example, are a technique which releases the writer from both inner and outer fear.

Caricature is another essential device used in descriptive writing and visual arts, where particular aspects of a subject are exaggerated to create a silly or comic effect. In other words, it can be defined as a plastic illustration, derisive drawing or a portrayal based on exaggeration of natural features, which gives a humorous touch to the subject. Equally essential is dramatic irony, a stylistic device that is most commonly used in narratives, plays, and movies. As a plot device, irony is employed to create situations where the reader knows much about the episodes in question and their resolutions before the main characters do (Battish, 1983).

Since the thread that separates satire and buffoonery is very thin, a satirical piece of writing should have a clear aim and benefit (Aldammam, 2010). A satirical writer should be cheerful, open-minded and enlightened.

Arab satirical literature seems to have set itself apart qualitatively and quantitatively. This richness of satirical writing is due to the huge amount of contradictions found in Arab societies. Criticizing such contradictions is the first step towards social change. Dulaimi (2011) believes that writers should identify the content of the prevailing culture in a given society before choosing the written genre they will use. 


\subsection{Historical Roots of Satire}

The development of satire is connected with Greek philosophy in general and Socrates' philosophy in particular. Socrates made satire the basis of his philosophical debates with sophists. He would ask naïve questions and they would reply. Then more complicated questions would emerge. Thus, satire was a tool of inference, proving and convincing. For Socrates, satire equals intelligence and wisdom.

\subsection{Types of Satire}

Satire has three main types: ironic, mental, and humorous (Zadah, 1972). Ironic satire aims at mocking various social phenomena through making fun of certain persons or groups. These phenomena can be social, political, literary, behavioral, etc. Mental satire is connected with the mu'tazila, who practiced the art of mocking according to their own philosophy of life, based on sympathizing with ordinary people and guiding them to an awareness of their vices to correct them. Aljahiz's satire of black people is a good example of this type of satire.

\subsection{The Role of Satirical Writing}

Writers use satire to achieve the following goals:

1. To deal with political issues mockingly in an indirect way that helps them escape punishment as when a satirist ridicules a dictators and corrupt figures.

2. To help achieve social reform and maintain social unity through laughter which psychologists claim is used by a society to attack the people who do not respect social rules and to help reform such people.

3. To protect a society against 'cultural invasion'. Westernization, for example, can be resisted by mocking the people who adopt Western customs which clash with the social traditions of a certain society. Psychologists believe that a social group may protect itself by mocking other groups.

4. To bring about social change by unsettling social sediment. This way, satire performs the role of both criticizing and reforming societies (Alsharabi, 2012).

As the above listing shows, the major role of satirical writing is to reveal or uncover the serious political and social defects of a community to help form certain political, social, cultural, and economic concepts in the minds of the audience and to ultimately help modify individual behavior. Through the modification of individual behavior, social change can be achieved. Achieving such results depends on both the sender and the receiver

\subsection{The Emergence of Satire in World Press}

Satirical writing began in the Western press in the form of caricature drawings. Such drawings were found to have a profound effect on the reader. Then, the comic cartoons transformed into satirical writings that handled various critical issues in societies, particularly under the influence of the complexity and seriousness of life and reality, which calls for a genre which conveys all this to the reader in a comic and indirect reform-oriented way. Satirical writing in the press is so implicit that it can say what it wants and hides beyond its linguistic and non-linguistic tools. In other words, a satirical writer can say what a serious writer cannot convey. This has made the satirical press the voice of the public, expressing the dreams and hopes of ordinary people (Alsharabi, 2012).

The journalistic style is explicit, pierce, accurate and vivid. It is a group of distinctive attributes that distinguish one writer from another. These attributes are innate and cannot be acquired through practice (Aljindi, 1967).

\subsection{Satire in Saudi Press}

The satirical style of writing is appropriate for contemporary issues arising from the conflicts in Arab societies, the corruption of political and administrative systems and the ravages of colonialism. This may be why Arab writers resort to satire in the portrayal of daily misfortunes and sufferings (Mashtoob, 2011).

Arab writers began to imitate the western style of writing described above. The beginning was in the writings of Yaqub Sannu in his journal "The Man in Blue Glasses" (Abu Naddarah Zarqaa). Sannu is known as the master of satirical writing in the modern age (Ibrahim, 2013).In the Saudi press, satirical writing is rare, unlike the case in other Arab press. It can be found in daily or weekly columns of few 
Saudi writers such as Ahmed Sabai, Muhamad Hassan Awad, and Fahd Arifi. Aldammam (2010) states that the social norms and religious prohibitions of the Saudi society are the major reasons for the scarcity of satirical writing in Saudi press.

\section{Khalaf AlHarbi as a SAUdi SATIRIST}

Khalaf Alharbi is a Saudi writer and poet on Okaz newspaper. He writes five times a week in his column 'On Two Streets'. He was the editor-in-chief of Shams magazine and one of the founders of Mukhtalif magazine. He has also written many TV series and programs such as Tash Ma Tash, Wifi, Almassaqil and Nowayir and her Kids.

As a creative writer, Alharbi has developed a style which uses words that are more like shots fired at the heart of corruption, making a kind of social criticism which is full of black comedy. For him, satirical writing is a method of producing tears not smiles. He shifts from drama to poetry to journalism to convey his message as he boldly handles local affairs. He monitors the social, intellectual, and cultural aspects of the Saudi society with the eyes of a citizen who loves his home country. His 'satirical project' tends to enhance the collective project and dismantle the angelic look of the society (Alharbi, 2015).

In addition to his journalistic satire, Alharbi uses TV drama to treat the political issues of the Arab world, which occupy a large space in his writings. Believing that the main aim of criticism is rehabilitation, Alharbi keeps in mind the fine line between criticism and cynicism.

Alharbi (2015) demonstrates that a satirical writer should understand the general mood of the readers to be able to create laughter and that the atmosphere of freedom versus repression affects the quality of satirical writing. A satirical writer in a country that does not enjoy much freedom needs to use many writing tricks to safely convey his ideas. On the other hand, a writer in a country that enjoys more freedom searches for innovative writing tricks to achieve the goals of surprise and shock. In either case, the writer depends on his wit and knowledge. In this respect, Alharbi describes the satirical writer who lacks knowledge as a funny talkative person, not a real satirical writer.

\subsection{Examples of Alharbi's Satirical Articles}

\section{The News of the Electronic Manor}

Fabrication is associated with the yellow press. In some Arab countries, lathing shops are sometimes called 'fabrication shops'. Some electronic newspapers depend on fabrication in all news reporting. We can call them 'lathing newspapers'. These electronic papers are run by a group of people who cannot have an opportunity to write in print newspapers due to their weak skills. They launch such electronic sites that are full of fabricated photos and false news. They think that this electronic manor can be an 'electronic newspaper'. Yes, there are attempts to launch respected electronic newspapers, but they are rare.

Unfortunately, these publications exist in the forefront of the Saudi electronic media. They lack objectivity and credibility. They resemble lathing shops; journalists can fabricate photos to take revenge upon their rivals or to distort news to suit the vision of the manor. Sometimes, these papers are accused of intellectual terrorism as they aim to ruin the reputation of their enemies through publishing fake news. Here are some examples of the headlines of news stories published on these sites: "A famous journalist arrested with a huge amount of drugs", "A famous football player kidnaps a child", and "A financial crisis forces a major newspaper to fire all editors and journalists, sparing printing press workers". If the published news is a cocktail of lies, the responses of the readers are a cocktail of insults and racial slurs, especially if the news is about a woman.

All these electronic manors are not ready to pay a penny to improve the standard of journalists and editors. Their easy way to fame and popularity is publishing false news" (Alharbi, 2015).

\section{If You Boast, We will Boast Back}

“Two years ago, Halima Boland won a 'Miss Announcer' contest which was held in Beirut. The title was designed just for her. Some Lebanese journalists said that the prize and the party were fabricated. In a phone interview, Boland tried to defend her title, but the host asked her a sudden question: "Who won second prize?" She kept silent. 
During the next few days, the Alnasrsporting club will celebrate the tenth anniversary of its World Cup qualification. The celebration came after the declaration of Alhelal sporting club as Asia's Club of the Century. When we asked them who gave you the title, they replied, "The international federation of statistics". The celebration of Alnasr club is much more ridiculous than the title of Alhelal as it is the first time a team celebrates its failure to gain any title or championship for ten successive years.

Such athletic titles are a minor absurdity compared with the international awards that we get in the fields of environment and wildlife protection. The systematic pollution of the sea at Jeddah should preclude our talking about environmental protection. A short visit to "Mahd Alzahab" proves that we have failed to understand that environmental pollution kills humans. The factories in the south of Riyadh prove the same fact. Despite tampering with the environment, we win from time to time international awards in recognition of our exceptional efforts to protect the environment.

I was once surprised to read that a Saudi woman got the title of 'The most beautiful woman in the world' according to a rating by an unknown international institution. I was surprised how this international institution reached this result while most Saudi women cover their faces. I resisted my deep desire to discredit the eligibility of Saudi women to get the international title defeating the Hungarian woman who came in second place.

I decided to celebrate this great victory by shouting, "Our women get the title of the most beautiful woman and our men win the world cup of mental disability. Praise be to Allaah!"

\section{Don't Misunderstand}

For forty-eight hours, this small paper has been with me in three cities and on airplanes. Everything could have been lost in this hurry except this small useless paper. I found it in the last airport while I was looking for another paper. This has happened millions of times during these forty-eight hours. At last, I surrendered and decided to read the paper carefully. I was astonished; the paper was like a magician's talismans.

I found many unreadable notes written in every corner of this paper -'Bus Coup in Ecuador', 'Prepottery Communities', 'Byzantine Aristocratic Family', 'Tabook-Jawf Road', 'Syrian-Japanese Mission', 'Neolithic Age', etc. Really, I didn't understand anything, but I decided to try to understand these talismans on the airplane and not tear the paper up. I hid it in a pocket in my bag between a set of papers, cards and bills like any novice smuggler, but I remembered that the screening devices at the airport are busy with the trapped parcels, so, I put it in my upper pocket.

On the airplane, I began analyzing the paper. I remembered a message from my friend Fahd Alblewi. He was surprised that the local TV didn't broadcast the news about eight persons killed and ten injured in a traffic accident on the Tabook-Jawf road while it announced the death of someone in a bus coup in Ecuador. I remembered that Fahd focused on the bad single roads that harvest the innocent souls for free. After a while, I remembered that one night, I watched a TV report about the discovery of some artifacts in the Tel Karkh district from the New Stone Age by the Syrian-Japanese archeological expedition. At this time, I laughed when I imagined the people who lived in that age mocking the way of living of the Old Stone Age. Excavations revealed some artifacts traced back top re-pottery communities. I don't know why I felt that I knew those communities. I envied them because they could live side by side with the nano-communities without feeling any different. The report went on to say that the expedition discovered a Byzantine aristocratic Family tomb. I changed the channel, only to find myself in front of the Rotana Clip Channel. I thought to myself, "This is a good chance for relaxation before the news". Again, I was surprised to see the singer Amal Hijazi looking at her unfaithful lover and telling him, "I thought you were a man". At this point, I realized that miscalculations result from misunderstanding.

\section{Vapid Jokes in Jeddah}

Dear the mayor of Jeddah, on the occasion of the opening of the Rawdha tunnel on Thursday and its sinking and cracking on Friday, will you submit the project to the Kleenex company?

Dear the vice-mayor of Jeddah, on the occasion of your announcement of the transformation of the King Abdullah tunnel into a rainwater drain because of the lack of a rainwater drainage system, do you suggest that the inhabitants of Jeddah should complain to the municipality of Hafr Albatin? 
Dear secondary school students of Jeddah who participated in the Olympics of scientific innovation with floating cars, have you lost hope of finding a solution to the rain-related disasters in Jeddah?

Dear youths who took their hooks to fish in one of Jeddah's tunnels, do you think fishing is possible there?

Dear mouth, on the occasion of flooding without the need to demolish the dam, do you want to prove that you are stronger than the legendary mouse that brought down the Mareb Dam?

Dear King Abdul Aziz University, when you ask your students to leave campus during rain, do you think that they are frogs?

Dear Nizar Qabbani, when, you said "I breathed under water" in one of your poems, did you mean that you had a date with someone there?

Dear Palestine Street, on the occasion of closing your entrances and exits, do Jeddah inhabitants need a map to locate their homes?

Dearmayor of Jeddah, when you assert the necessity of solving the problems of Jeddah, do you think that the security man should resign?

\section{Australia, We Need the Device}

An Australian scientist was awarded the Nobel Prize for scientific folly. He invented a device that returns a boiled egg to its original state. The news mentioned that this device has so many benefits related to chemical therapy and protein extraction that the chemist was surprised with the success of his device.

The Nobel Prize for scientific folly is awarded to useless inventions. On the same day, I read the declaration of the father of Alshamli terrorists who killed their cousin and two policemen. The father asserted that the Internet spoiled his elder son Saad. Saad used to sit for long hours in front of the computer. He declared that the Internet and social media are smart bombs in the hands of five-year old children. Instead of improving awareness and increasing human communication, the Internet and social media became tools of publicizing aggressive ideas and promoting religious intolerance.

The followers of the sick terrorist ideas published through social media, especially Twitter, can realize its dangerous effect on ignorant people and youths. This is why some Saudi writers have called for banning Twitter. I think that idea is impossible. I think that the Australian device is the only solution. We can bring the device and distribute it. Whenever a boy uses the Internet and immerses himself in such racial and ethnic debates, the parents should be waiting outside his room to put the device on his head. The device will return his mentality to its original state" (Alharbi, 2015).

\subsection{Khalaf Alharbi's satirical style}

Regarding his topics and purposes as a writer, Alharbiuses satire to boldly criticize his society in an ironic language full of laughter and humor. He selects a number of Saudi daily issues as material for his articles. In his works, satire functions as an instrument that grants the writer the freedom of expression he needs to call for change, particularly as regards social injustice. However, while he mocks individual and social defects, Alharbi defends human values and honours conscience.

Alharbi's satirical style depends on irony and contradictions. He plays with words to evoke laughter and pass his ideas. His articles depend on the three pillars of satirical literary texts - narration, stylistics, and semantics. Narration deals with an idea about a certain social reality. Stylistics means the choice of sentences, expressions and ironic devices. Semantics involves the use of reference and implication to convey a hidden meaning.

Style can be defined as the author's choice of words, sentence structure, and figurative language (Abdullatif, 1984). In this respect, it can be said that Alharbi's articles show him to convey his ideas in a very simple style, balancing such contradictions as beauty and ugliness, life and death, good and bad reputation, etc. His articles can be considered a kind of catharsis in its positive sense. Catharsis prevents tension and relaxes people (Aljamal, 2010).

Concerning his vocabulary, Alharbi prefers short common words, including Arabized items, and avoids 'difficult' words. In other words, he uses a modern and not a classical variety of Arabic to convey his ideas in a way full of hints and implications His vocabulary suits the social, cultural and 
political concepts. To achieve his aims, Alharbi uses a variety of rhetorical devices such as metaphor, pun, trope, metonymy, simile, periphrasis, symbols, circumlocution, exaggeration and gesticulation, as described in Altha' alibi (1992). Thus, richness of meaning and accuracy of images are also achieved.

Alharbi's sentences are short and simple, contain no fronted place or time adverbs, express one idea per sentence, and do not contain repetitions or complex grammatical structures. His paragraphs are short, mostly four to five sentences. This way, his style attracts the reader and urges him to continue reading.

All these characteristics enable the reader to grasp the intended meaning. In these respects, Alharbi's style agrees with the requirement that journalistic articles should be written in everyday language so that it can be understood by the largest number of readers (Hamzah, 1967).

\section{Conclusion}

The above analysis of the style of the Saudi Writer, Khalaf Alharbi, has revealed that:

1. Alharbi's satire can be described as lampoon or satire.

2. His satirical style is realized by the paradox formed by the contradiction between explicit and embedded meanings.

3. His satire reveals the shortcomings of the Saudi society in an ironic manner.

4. As he mocks follies he also respects human values and honours conscience.

5. He uses a simple language, preferring short, simple words from everyday life.

6. He uses a wide variety of rhetorical devices.

\section{REFERENCES}

Abdullatif, Muhamad (1984). Style and Stylistics. Book Association, Cairo.

Abuhajam, Muhamad (2004). The irony of modern Algerian literature. Algiers: Heritage Association.

Abukhalil, Ahmad (2006). The Poverty of Philosophy: Exercises in Satirical Writing. Amman: Alahliah for Publishing and Distribution.

Akkari, Susan (1991). Satire in Antoine Ghandour Theater. Beirut: Modern Book Foundation.

Alabban, Sherif Darwish (2014). Iorny Theory and Bringing down the Egyptian State. Cairo: Albawabah News daily.

Alamuddeen, Mahmood (1990). Information Technology and Mass Communication Industry. Cairo: Alaraby for publishing and distribution.

Aldammam, Salem Salman (2010).Satirical Writing Fades Away from Saudi Press.Asharq alAwsatdaily, V.1611.

Alharbi, Khalaf (2015). The Irony Volcano Explodes Black Comedy. 20 December.

Aljamal, Eman (2008). Exposure in the poetry of Abdul Karim al-Qaisi. Journal of the thought and creativity, Association of Modern Literature. Cairo: Dar Alebdaa'.

Aljamal, Eman (2010). The rhythm of contradictions in Hariri's Maqamaat.Journal of the Faculty of Arts, Mounofia University.

Aljindi, Anwar (1967). The Development of Arabic Press and its Impact on Contemporary Arabic Literature.Cairo: Alrsalah Publisher.

Alkhasawneh, Ibrahim Fouad (2012).Specialized Press. Dar Almasirah for Publishing and Distribution, Amman.

Alsharabi, Salam Najmuddeen (2012).The Principles of Satirical Writing.LahaOnlinehttp:// www.lahaonline.com/articles/view/40432.htm.

Altha'alibi, Abumansour (1995). Metonymy and exposure. Soussah, Tunisia: Dar Alma'arif,.

Battish, Simon (1983).Humor and irony in Maroun Abboud's Works. Beirut: Dar Lana.

Daif,Shawqi (1999). Humor in Egypt. Cairo: Dar AL Maaref.

Dulaimi, Abdul razaq Mohamed (2011).The News in the Media. Amman: Dar Al Masirah for publishing and distribution. 
Dulaimi, Abdulaziz (2011).International Press. Amman: Dar Almasirah for Publishing and Distribution.

Ezzat, Mohamed Fareed (1998). Articles and Press Reports: Preparation and Writing. Cairo:AldarAlalamyah.

Fathi, Ibrahim (1986). Dictionary of Literary Terms. Sfax, Tunisia: Arab Foundation of United Publishers.

Hamza, Abdullatif (1967).An Introduction to Press Editing. Cairo: Dar Alfikr Alarabi.

Ibnmanzour, Abu Alfadl Jamalluddeen Muhamad Ibnmakram (1990). The Arab Tongue. Beirut: Dar Sader.

Ibrahim, Reham Abdu (2013).The Role of Satirical Press in the Egyptian Patriotic Movement (18781910): An Empirical Study. M.A. Faculty of Mass Media.Cairo University.

Mashtoob, Samiah(2011). Satire and its manifestations in contemporary Algerian press. M.A. Thesis, University of Mouloud Mammeri. Algeria.

Omari, Muhamad (2005).New Rhetoric between Imagination and Deliberation. Casa Blanka: Africa and East, Dar Al-Baydaa

Zadah, Waqif Shamsi (1972).Satirical Literature: Types and Development. 